\section{Assessment of reinforcement in polymer nanocomposites using cumulative rheological parameters}

\author{
MILAN KRACALIK - Institute of Polymer Science, Johannes Kepler University - Milan.Kracalik@jku.at \\ Érkezett: 2017. 10. 26. " Received: 26. 10. 2017. - https://doi.org/10.14382/epitoanyag-jsbcm.2017.21
}

\begin{abstract}
Multiphase polymer systems, like polymer nanocomposites, exhibit complex rheological behaviour due to physical and also possibly chemical interactions between individual phases. Up to now, rheology of dispersive polymer systems has been usually described by evaluation of viscosity curve (shear thinning phenomenon), storage modulus curve (formation of secondary plateau) or plotting information about dumping behaviour (e.g. Van Gurp-Palmen-plot, comparison of loss factor $\tan \delta$ ). On the contrary to evaluation of damping behaviour, values of cot $\delta$ were calculated and called as „storage factor“, analogically to loss factor. Then values of storage factor were integrated over specific frequency range and called as "cumulative storage factor". In this contribution, LDPE-ZnO-clay nanocomposites with different dispersion grades (physical networks) have been prepared and characterized by both conventional as well as novel analysis approach. Next to cumulative storage factor, further cumulative rheological parameters like cumulative complex viscosity, cumulative complex modulus or cumulative storage modulus have been introduced.
\end{abstract}

Keywords: shear flow, oscillatory shear, polymer, clay, nanocomposites

Kulcsszavak: nyírási folyás, oszcilláló nyírás, polimer, agyag, nanokompozit
Prof. Dr. Milan KRACALIK

is assistant professor at the Institute of Polymer Science, Johannes Kepler University Linz. His field of expertise covers in particular polymer rheology, polymer composites and nanocomposites, polymer recycling, study of structure-properties relationship in polymer materials and management associated with technological processes and products. He studied Technology \& Management at the Brno University of Technology, Czech Republic (MSc.: 2000), at Tomas Bata University in Zlin and Institute of Macromolecular Chemistry, Academy of Sciences of the Czech Republic

(Ph.D.: 2006) associated with praxis in marketing department of Podravka-Lagris Inc., Czech Republic. Between 2006 and 2012 he was post-doc researcher \& project leader at the Department of Polymer Engineering and Science of the University of Leoben, Austria. Between 2012 and 2014 he was research manager at the Department Research and Development of the ISOVOLTAIC AG, Austria. He has also lectured on Technology \& Management at several European universities such as Albert Ludwigs University Freiburg, Budapest University of Technology and Economics, Chemical Research Centre / Hungarian Academy of Sciences, University of Zagreb and Department of Technical Sciences / Croatian Academy of Sciences and Art.

\section{Introduction}

Polymer nanocomposites using organically modified clays have been intensively investigated due to enhancement of processing as well as utility properties. Using nanoparticles is an interesting way for preparation of polymer tailored materials. The enhancement of material properties because of nanoparticles addition has usually been analysed using a combination of morphological (X-ray diffraction (XRD), transmission electron microscopy (TEM)), mechanical (tensile testing) and possibly rheological (rotational rheometry) measurements [1-17]. Using 2-5\% of clay, significant improvement of material properties can be reached: high elastic modulus, tensile strength, thermal resistivity, low gas and liquid permeability, reduced flammability [18] and improved rheological properties compared to the unfilled polymer matrix [1-17]. High reinforcement due to addition of the layered silicates results from their large surface area (specific surface of montmorillonite is about $700-800 \mathrm{~m}^{2} / \mathrm{g}$ ) $[19,20]$. In the case of highly dispersed systems, a three dimensional physical network is achieved, formed due to interactions between silicate platelets and the polymer chains. This phenomenon can be investigated by analysis of the melt elasticity using rotational rheometry [140]. These studies are mainly based on evaluation of viscosity curve shape (shear thinning phenomenon), storage modulus curve at low frequencies (formation of secondary plateau), phase homogeneity (Cole-Cole plot) or plotting information about dumping behaviour (e.g. Van Gurp-Palmen-plot, comparison of loss factor $\tan \delta$ ). In order to enable simple comparison of nanocomposites reinforcement in the shear flow, new way to analyze data of the shear flow has been tested $[31,32]$. The storage modulus $G^{\prime}$ describes the elastic part while the loss modulus provides us with information about the viscous part of the shear flow. The relation $G^{\prime \prime} / G^{\prime}$ is defined as $\tan \delta$ and reflects damping behaviour in the polymer system. According available literature, the $G^{\prime} / G^{\prime \prime}$ ratio $(\cot \delta)$ has not been used for rheological evaluation of nanocomposites up to now. Compared to $\tan \delta$ (loss factor), $\cot \delta$ (called as storage factor, $\mathrm{SF}$ ) reflects melt rigidity, which can be associated with reinforcement effect in polymer (combination of chain elasticity with silicate layers rigidity in the polymer melt). In order to reduce the magnitudes of storage factor to one representative value for one sample, $G^{\prime}$ as well as $G^{\prime \prime}$ curves have been integrated over the measured frequency range as following:

$$
C S F=\int_{0.1 \mathrm{rad} / \mathrm{s}}^{628 \mathrm{rad} / \mathrm{s}} G^{\prime} / \int_{0.1 \mathrm{rad} / \mathrm{s}}^{628 \mathrm{rad} / \mathrm{s}} G^{\prime \prime}
$$

In this way, cumulative storage factor (CSF) and some further cumulative rheological parameters (e.g. cumulative complex viscosity $\mathrm{CCV}$, cumulative complex modulus CCM, cumulative storage modulus CSM) were introduced [31]. It was proven that values of CSF can be correlated with values of melt strength, i.e. the reinforcement in polymer nanocomposites can be assessed and compared in both, shear as well in elongational flow [32]. In this paper, LDPE-ZnO-clay nanocomposites with different dispersion grades (physical networks) are reported. It is shown that nano-scaled $\mathrm{ZnO}$ can be used not only as UV stabilizer but also as reinforcement and dispersion agent, respectively. The obtained data is analysed in this paper using typical rheological approaches as well as cumulative rheological parameters like CSF or CCV. 


\section{Materials and Method}

CA9150 low-density polyethylene for extrusion coating has been used for the preparation of nanocomposites (supplied by Borealis Inc., Linz, Austria). The used nanoclay Cloisite $20(\mathrm{Cl} 20)$ as well as LDPE masterbatch with $30 \%$ nano-scaled $\mathrm{ZnO}$ (Nanobyk) were supplied by BYK-Chemie Ltd, Wesel, Germany / POLYchem Ltd, Markt Allhau, Austria, respectively.

Mixtures have been prepared using laboratory compounder MiniLab II Haake Rheomex CTW5 (Thermo Fisher Scientific, Germany). Performance of four different compositions (pure PE matrix, 5wt.\% of $\mathrm{Cl} 20$, 5wt.\% of $\mathrm{ZnO}, 2.5 / 2.5$ wt.\% of $\mathrm{Cl} 20$ / $\mathrm{ZnO}$ ) have been compared. Rheological properties in the shear flow were studied using a Physica MCR 502 rheometer (Anton Paar Ltd., Graz, Austria) with the cone-plate geometry of 25 $\mathrm{mm}$ diameter and measuring gap of $43 \mu \mathrm{m}$.

\section{Results \& Discussion}

The nanocomposites dispersion grade and effect of matrix molecular weight on final morphology can be evaluated using analysis of viscosity curve (shear-thinning effect) in combination with information obtained from the storage modulus curve ( $\mathrm{G}^{\prime}$ secondary plateau; [33]). In Figs. 1 and 2, magnitudes of complex viscosity as well as storage modulus in dependency on angular frequency were plotted. As can be seen from Fig. 1, the systems prepared with $\mathrm{Cl} 20$ and $\mathrm{Cl} 20$ / $\mathrm{ZnO}$ revealed pronounced shear-thinning behavior, as result of disruption of network structures and, consequently, by orientation of filler particles in flow. On the other hand, CA9150 matrix as well as nanocomposite only with $\mathrm{ZnO}$ showed typical liquid viscoelastic behaviour. The lower viscosity values of nanocomposite only with $\mathrm{ZnO}$ comparing with pure CA9150 matrix can be explained by significantly lower viscosity of LDPE matrix used for preparation of $\mathrm{ZnO}$ masterbatch. Therefore, higher admixture of $\mathrm{ZnO}$ masterbatch to CA9150 matrix results to higher "dilution" of CA9150 matrix, i.e. the average molecular weight in such polymer blend will be lowered.

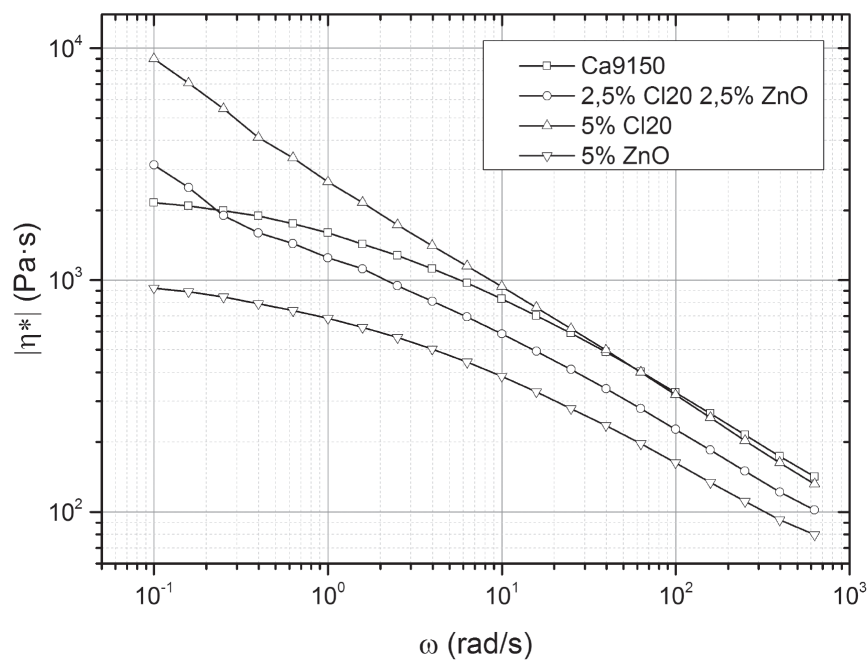

Fig. 1. Complex viscosity of nanocomposites

1. ábra Nanokompozitok komplex viszkozitása
For systems with high dispersion grade, the dependence of $G^{\prime}(\omega)$ becomes almost invariable at low frequencies. Such "secondary" plateau indicates the formation of a network structure ("rubber-like" behavior) reflecting the exfoliation of silicate layers in nanocomposites [34, 47, 48]. As can be seen in Fig. 2, systems prepared with $\mathrm{Cl} 20$ and $\mathrm{Cl} 20 / \mathrm{ZnO}$ showed "rubber-like" behaviour i.e. high dispersion grade, while pure CA9150 matrix as well as nanocomposite with $\mathrm{ZnO}$ exhibited typical viscoelastic behaviour. It means, in 2.5 $\mathrm{Cl} 20 / 2.5 \mathrm{ZnO}$ nanocomposite, two physical interactions are acting simultaneously: on one hand, melt elasticity is increased by formation of 3D-physical nework between polymer chains and silicate platelets, and, on the other hand melt elasticity is decreased due to decrease in polymer average molecular weight. As can be seen from Figs. 1 and 2, the decrease in polymer average molecular weight is dominating in $5 \% \mathrm{ZnO}$ nanocomposite system comparing to pure CA9150 matrix.

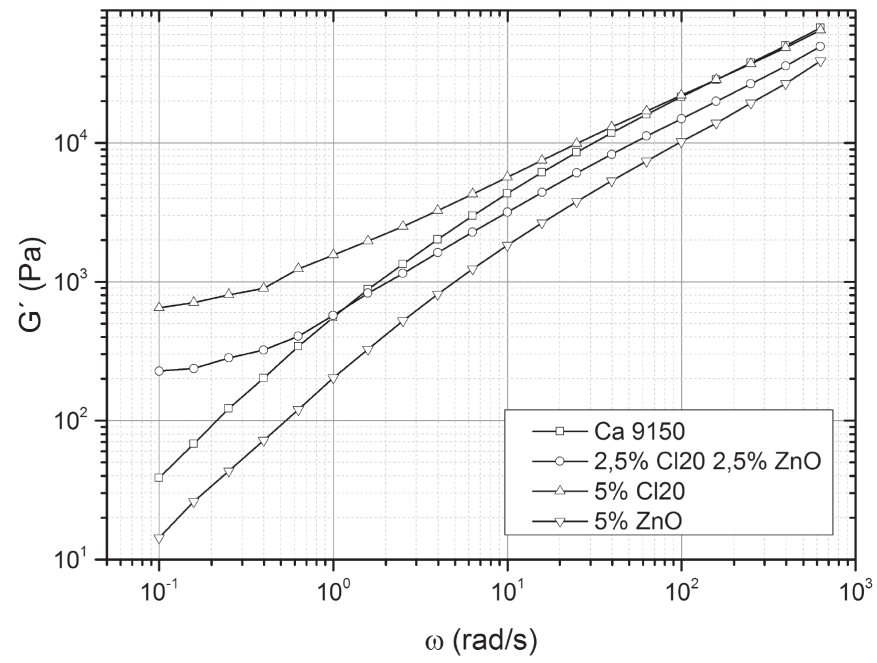

Fig. 2. Storage modulus of nanocomposites

2. ábra Nanokompozitok tárolási modulusa

The van Gurp-Palmen (vGP) plot as a dependency of loss angle $\delta$ on complex modulus $\left|G^{\star}\right|$ can be used to analyze the spatial structures of polymers [41-45]. In Fig. 3, vGP plot is shown for prepared samples. For the polymer samples with rather linear chain structure, a continuous shaped curve has been published. On the contrary, long chain branched (LCB) polymers showed a developed bump between the $\left|G^{*}\right|$ minimum and the $90^{\circ}$ plateau [44]. As can be seen in Fig. 3 , systems prepared with $\mathrm{Cl} 20$ and $\mathrm{Cl} 20 / \mathrm{ZnO}$ show spatial structure similar to mentioned LCB polymers with even two bumps or peaks (Cl20), indicating complex $3 \mathrm{D}$ structure made of filler and polymer chains [49]. The CA9150 matrix and nanocomposite with $\mathrm{ZnO}$ exhibit behaviour connected with linear chain structure. In order to get additional information about viscoelastic damping behaviour of the prepared samples, phase shift $\delta$ in dependency on angular frequency has been plotted (Fig. 4). The curves are similar to those of vGP and confirm formation of differently organized structures (combination of agglomerated, delaminated and exfoliated structure) depending on achieved 3D network. 


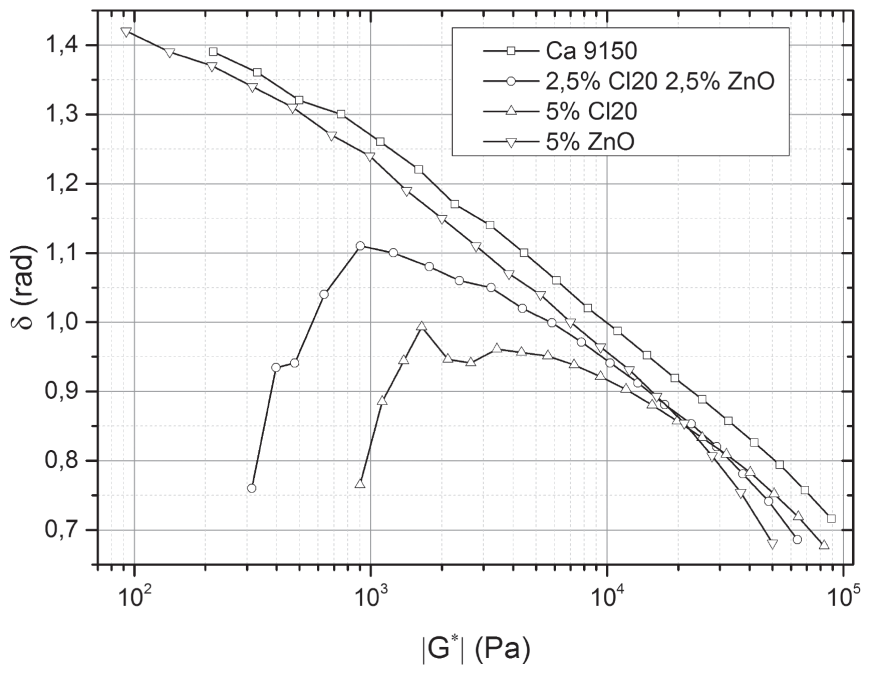

Fig. 3. Van Gurp-Palmen plot of nanocomposites

3. ábra Nanokompozitok Van Gurp-Palmen diagramja

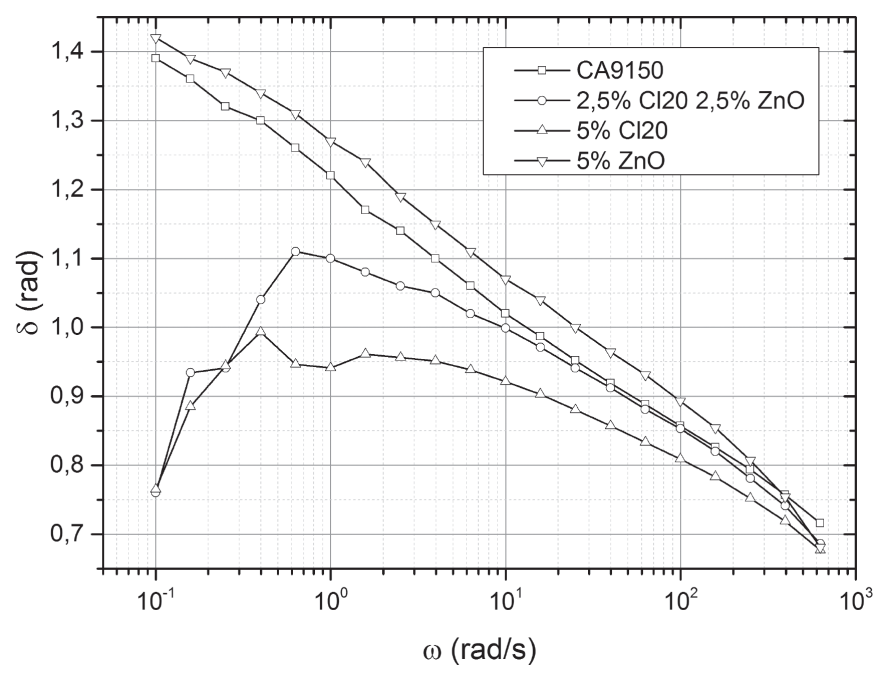

Fig. 4. Phase shift in dependency on angular frequency

4. ábra Fáziseltolódás a szögfrekvencia függvényében

Another approach for description of viscoelastic damping behaviour is so called "Cole-Cole" figure, in which imaginary part of complex viscosity over the real part is plotted. This figure has been widely used to assess miscibility/homogeneity of polymer blends and composites in the way that a smooth, semi-circular shape can be interpreted by better compatibility and homogeneity, respectively [23,46]. As shown in Fig. 5 the CA9150 matrix and nanocomposite with $\mathrm{ZnO}$ showed semi-circle shapes, reflecting high homogeneity of the system. However, for the analysis of polymer nanocomposites performance, not only homogeneity but also reinforcement should be addressed. Using Cole-Cole plot, it can be said, that systems prepared with $\mathrm{Cl} 20$ and $\mathrm{Cl} 20 / \mathrm{ZnO}$ revealed deviation from semi-circle shape and, therefore, are rather not homogeneous. Nevertheless, no information about reinforcement level can be obtained from this figure and this problem is actually concomitant with each previously described rheological analysis based on damping behaviour.

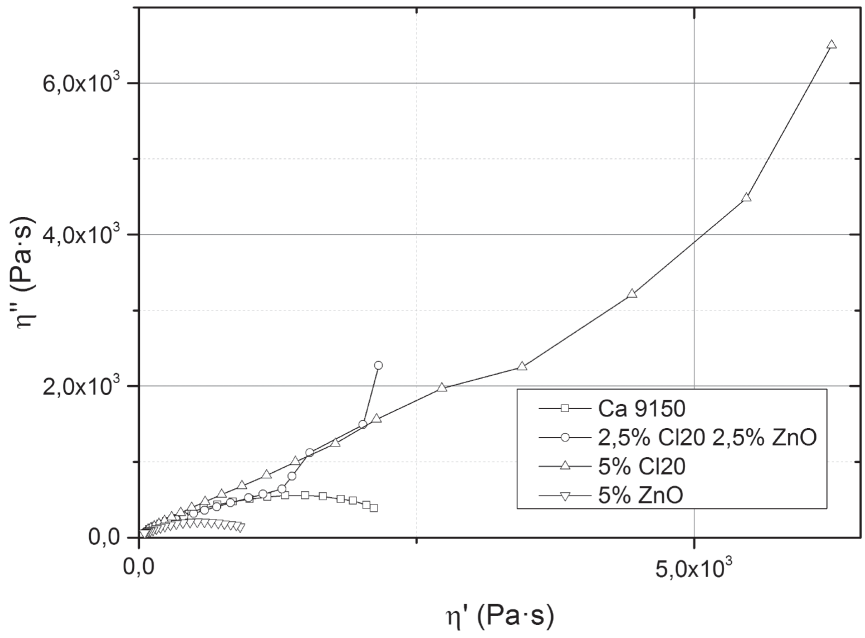

Fig. 5. Cole-Cole plot

5. ábra Cole-Cole diagram

Using previously introduced analysis based on "rigidity" behaviour [31, 32], there is possibility to analyze reinforcement level as result of 3D physical network between polymer chains and filler particles and, consequently, to obtain some information hidden in analysis based on damping behaviour.

The CSF plotted over CCV in Fig. 6 shows clearly other trend as trends obtained from figures analyzed previously in this paper. For CA9150 matrix it can be seen that viscosity value is high, but reinforcement level represented by CSF (comparing to all nanocomposites) is low. Comparing to CA9150, the nanocomposite with $5 \%$ of $\mathrm{ZnO}$ revealed lower value of viscosity, but higher value of reinforcement, followed by nanocomposite with $2.5 / 2.5$ wt.\% of $\mathrm{Cl} 20 / \mathrm{ZnO}$ and finally followed by nanocomposite with $5 \mathrm{wt} . \%$ of $\mathrm{Cl} 20$ showing the highest reinforcement and approximately same level of viscosity. In this way, it was possible to divide contribution of "internal reinforcement" coming from internal friction (high molecular weight and viscosity values, respectively) represented by viscosity values - and "external reinforcement" coming from 3D physical network between polymer chains and nanofiller particles - represented by CSF values. This division was not possible to analyze using evaluation methods based on damping behaviour.

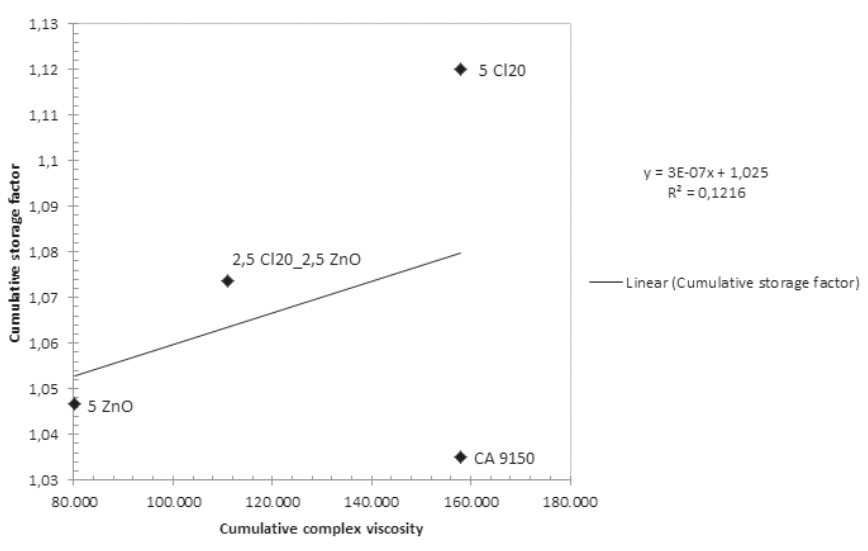

Fig. 6. Cumulative storage factor 6. ábra Kumulatív tárolási tényezö 
Comparing to Fig. 6, coefficient of linear regression in Fig. 7 is very high. It means, if only polymer nanocomposites are compared, there is high correlation between CSF and CCV values, giving possibility to compare previously described "external reinforcement" not only in cases of nanocomposites using one polymer matrix, but also in cases of nanocomposites based on polymer blends. This result will be proved in further work using not only polymer matrices with different molecular weight but also with different chemical compositions.

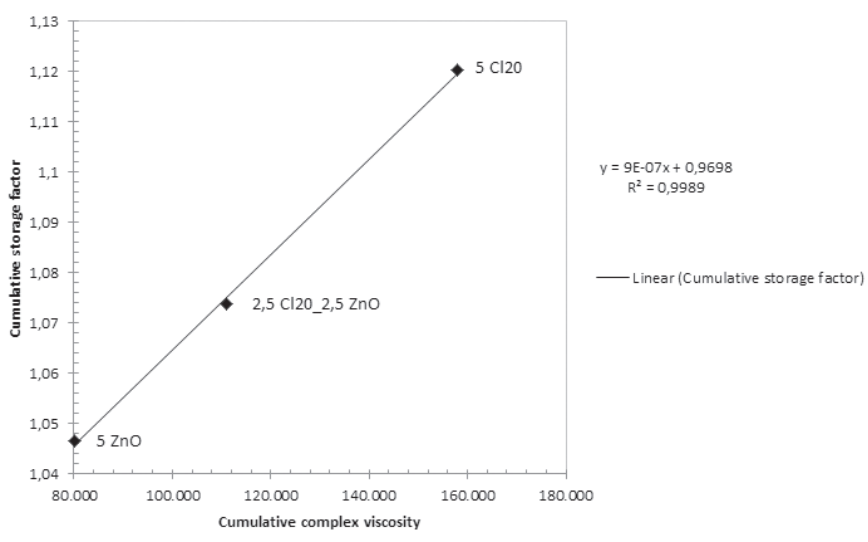

Fig. 7. Cumulative storage factor of nanocomposites without neat matrix 7. ábra Nanokompozitok kumulatív tárolási tényezője ágyazóanyag nélkül

\section{Conclusions}

Complex polymer nanocomposites with different molecular weight polyethylenes and clay/ $\mathrm{ZnO}$ nanoparticles were prepared and analyzed by conventional as well by new rheological approach. Using novel approach based on melt rigidity analysis the reinforcement caused by $3 \mathrm{D}$ physical network between polymer chains and nanofiller particles could be divided from that coming from internal friction (polymer molecular weight). In this way, new inside into performance characterization of polymer nanocomposites has been introduced and will be tested on nanocomposites based on different polymer blends in future work.

\section{References}

[1] Ray S. S. - Okamoto M. (2003): Polymer/layered silicate nanocomposites: a review from preparation to processing. Progress in Polymer Science, 28:1539-1641. https://doi.org/10.1016/j.progpolymsci.2003.08.002

[2] Ray S. S. - Yamada K. - Okamoto M. - Ueda K. (2003): New polylactidelayered silicate nanocomposites. 2. Concurrent improvements of material properties, biodegradability and melt rheology. Polymer, 44:857-866. https://doi.org/10.1016/S0032-3861(02)00818-2

[3] Laske S. - Witschnigg A. - Mattausch H. - Kracalik M. - Pinter G. Feuchter M. - Maier G. - Holzer C. (2012): Determining the ageing of polypropylene nanocomposites using rheological measurements. Applied Rheology, 22 (2), 24590 - 24599.

https://doi.org/10.3933/ApplRheol-22-24590

[4] Abdel-Goad M. (2011): Rheological characterization of melt compounded polypropylene/clay nanocomposites. Composites Part B, 42: 1044-1047. https://doi.org/10.1016/j.compositesb.2011.03.025

[5] Aghjeh M. R. - Asadi V. - Mehdijabbar P. et al. (2015): Application of linear rheology in determination of nanoclay localization in PLA/EVA/ Clay nanocomposites: Correlation with microstructure and thermal properties. Composites Part B, 86: 273-284.

https://doi.org/10.1016/j.compositesb.2015.09.064
[6] Ahmed J. - Auras R. - Kijchavengkul T. et al. (2012): Rheological, thermal and structural behavior of pol (e-caprolactone) and nanoclay blended films. Journal of Food Engineering, 111: 580-589. https://doi.org/10.1016/j.jfoodeng.2012.03.014

[7] Filippone G. - Carroccio S. C. - Curcuruto G. et al. (2015): Time-resolved rheology as a tool to monitor the progress of polymer degradation in the melt state e Part II: Thermal and thermo-oxidative degradation of polyamide 11/organo-clay nanocomposites. Polymer, 73: 102-110. https://doi.org/10.1016/j.polymer.2015.07.042

[8] Mishra J. K. - Hwang K-J. - Ha C-S. (2005): Preparation, mechanical and rheological properties of a thermoplastic polyolefin (TPO)/organoclay nanocomposite with reference to the effect of maleic anhydride modified polypropylene as a compatibilizer. Polymer, 46: 1995-2002. https://doi.org/10.1016/j.polymer.2004.12.044

[9] Nobile M. R. - Simon G. P. - Valentino O. et al. (2007): Rheological and Structure Investigation of Melt Mixed Multi-Walled Carbon Nanotube/PE Composites. Macromolecular Symposia 247: 78-87. https://doi.org/10.1002/masy.200750110

[10] Sadeghipour H. - Ebadi-Dehaghani H. - Ashouri D. et al. (2013): Effects of modified and non-modified clay on the rheological of high density polyethylene. Composites: Part B, 52: 164-171. https://doi.org/10.1016/j.compositesb.2013.04.010

[11] Samyn F. - Bourbigot S. - Jama C. et al. (2008): Crossed characterisation of polymer-layered silicate (PLS) nanocomposite morphology: TEM, $\mathrm{X}$-ray diffraction, rheology and solid-state nuclear magnetic resonance measurements. European Polymer Journal 44: 1642-1653. https://doi.org/10.1016/j.eurpolymj.2008.03.021

[12] Wagener R. - Reisinger T. J. G. (2003): A rheological method to compare the degree of exfoliation of nanocomposites. Polymer, 2003(44): 75137518. https://doi.org/10.1016/j.polymer.2003.01.001

[13] Wang M. - Fan X. - Thitsartarn W. et al. (2014): Rheological and mechanical properties of epoxy/clay nanocomposites with enhanced tensile and fracture toughnesses. Polymer, 58: 43-52. https://doi.org/10.1016/j.polymer.2014.12.042

[14] Zhang X. - Yang G. - Lin J. (2006): Synthesis, Rheology, and Morphology of Nylon-11/Layered Silicate Nanocomposite. Journal of Polymer Science: Part B: Polymer Physics, 44: 2161-2172. https://doi.org/10.1002/polb.20881

[15] Zhao J. - Morgan A. B. - Harris J. D. (2005): Rheological characterization of polystyrene-clay nanocomposites to compare the degree of exfoliation and dispersion. Polymer, 2005(46): 8641-8660. https://doi.org/10.1016/j.polymer.2005.04.038

[16]Zhao Y. - Huang H-X. (2008): Dynamic rheology and microstructure of polypropylene/clay nanocomposites prepared under $\mathrm{Sc}_{-} \mathrm{CO}_{2}$ by melt compounding. Polymer Testing, 27: 129-134.

https://doi.org/10.1016/j.polymertesting.2007.11.006

[17. Zhong Y. - Zhu Z. - Wang S-Q. (2005): Synthesis and rheological properties of polystyrene/layered silicate nanocomposite. Polymer, 46 (3006-3013). https://doi.org/10.1016/j.polymer.2005.02.014

[18] Gilman J. - Kashiwagi T. - Lichtenhan J. (1997): Nanocomposites: A revolutionary new flame retardant approach. Sampe Journal, 33:40-46.

[19] Lee K. M., Han C. D. (2003): Rheology of Organoclay Nanocomposites: Effects of Polymer Matrix/Organoclay Compatibility and the Gallery Distance of Organoclay. Macromolecules, 36:7165-7178. https://doi.org/10.1021/ma030302w

[20] Lee K. M. - Han C. D. (2003): Effect of hydrogen bonding on the rheology of polycarbonate/organoclay nanocomposites. Polymer, 44:4573-4588. https://doi.org/10.1016/S0032-3861(03)00444-0

[21] Ahmed J. - Varhney S. K. - Auras R. - Hwang S. W. (2010): Thermal and rheological properties of L-polylactide/polyethylene glycol/ silicate nanocomposites films. Journal of Food Science, 75: N97-N108. https://doi.org/10.1111/j.1750-3841.2010.01809.x

[22] Ahmed J. - Auras R. - Kijchavengkul T. - Varshney S. K. (2012): Rheological, thermal and structural behavior of poly(e-caprolactone) and nanoclay blended films. Journal of Food Engineering, 111: 580-589. https://doi.org/10.1016/j.jfoodeng.2012.03.014

[23] Aklonis J. J. - Macknight W. J. (1983): Introduction to viscoelasticity. New York: Wiley; 1983. 
[24] Gelfer M. - Song H. H. - Liu L. - Avila-Orta C. - Yang L. - Si M. - Hsiao B. S. - Chu B. - Rafailovich M. - Tsou A. H. (2002): Manipulating the microstructure and rheology in polymer-organoclay composites. Polymer Engineering and Science, 42:1841-1851. https://doi.org/10.1002/pen.11077

[25] Hoffmann B. - Dietrich C. - Thomann R. - Friedrich C. - Mülhaupt R. (2000): Morphology and rheology of polystyrene nanocomposites based upon organoclay. Macromolecular Rapid Communications, 21:57-61. https://doi.org/10.1002/(SICI)1521-3927(20000101)21:1<57::AID-MARC57>3.0.CO;2-E

[26] Hoffmann B. - Kressler J. - Stöppelmann G. - Friedrich C. - Kim G. M. (2000): Rheology of nanocomposites based on layered silicates and polyamide-12. Colloid and Polymer Science, 278:629-636. https://doi.org/10.1007/s003960000294

[27] Hyun Y. H. - Lim S. T. - Choi H. J. - Jhon M. S. (2001): Rheology of Poly(ethylene oxide)/Organoclay Nanocomposites. Macromolecules, 34:8084-8093. https://doi.org/10.1021/ma002191w

[28] Incarnato L. - Scarfato P. - Scatteia L. - Acierno D. (2004): Rheological behavior of new melt compounded copolyamide nanocomposites. Polymer, 45:3487-3496. https://doi.org/10.1016/j.polymer.2004.03.005

[29] Kim T. H. - Jang L. W. - Lee D. C. - Choi H. J. - Jhon M. W. (2002): Synthesis and Rheology of Intercalated Polystyrene/Na+-Montmorillonite Nanocomposites. Macromolecular Rapid Communications, 23:191-195. https://doi.org/10.1002/1521-3927(20020201)23:3<191::AID-MARC191>3.0.CO;2-H

[30] Kotsilkova R. (2002): Rheology-Structure Relationship of Polymer/ Layered Silicate Hybrids. Mechanics of Time-Dependent Materials, 6:283300. https://doi.org/10.1023/A:1016226118991

[31] Kracalik M. (2015): Rheology of Multiphase Polymer Systems using Novel „Melt Rigidity” Evaluation Approach. AIP Conference Proceedings, 1662: 040002-1 - 040002-6. https://doi.org/10.1063/1.4918890

[32] Kracalik M. - Laske S. - Witschnigg A. - Holzer C. (2011): Elongational and shear flow in polymer-clay nanocomposites measured by on-line extensional and off-line shear rheometry. Rheologica Acta, 50 (11-12): 937-944. https://doi.org/10.1007/s00397-011-0545-2

[33] Kracalik M. - Mikesova J. - Puffr R. - Baldrian J. - Thomann R. Friedrich C. (2007): Effect of 3D Structures on Recycled PET/Organoclay Nanocomposites. Polymer Bulletin, 58:313-319. https://doi.org/10.1007/s00289-006-0592-5

[34] Krishnamoorti R. - Giannelis E. P. (1997): Rheology of End-Tethered Polymer Layered Silicate Nanocomposites. Macromolecules, 30:40974102. https://doi.org/10.1021/ma960550a

[35] Mohagheghian M. - Ebadi-Dehaghani H. - Ashouri D. - Mousavian S. (2011): A Study on the effect of nano- $\mathrm{ZnO}$ on rheological and dynamic mechanical properties of polypropylene: experiments and models. Composites: Part B, 42:1987-93.

https://doi.org/10.1016/j.compositesb.2011.04.043

[36] Sadeghipour H. - Ebadi-Dehaghani H. - Ashouri D. - Mousavian S. Hashemi-Fesharaki M. - Gahrouei M. S. (2013): Effects of modified and non-modified clay on the rheological behaviour of high density polyethylene. Composites: Part B, 52: 164-171. https://doi.org/10.1016/j.compositesb.2013.04.010
[37] Sanchez-Solis A. - Garcia-Rejon A. - Manero O. (2003): Production of nanocomposites of PET-montmorillonite clay by an extrusion process. Macromolecular Symposia, 192:281-292. https://doi.org/10.1002/masy.200390038

[38] Sanchez-Solis A. - Romero-Ibarra I. - Estrada M. R. - Calderas F. Manero O. (2004): Mechanical and rheological studies on polyethylene terephthalate-montmorillonite nanocomposites. Polymer Engineering and Science, 44:1094-1102. https://doi.org/10.1002/pen.20102

[39] Solomon M. J. - Almusallam A. S. - Seefeldt K. F. - Somwangthanaroj A. - Varadan P. (2001): Rheology of Polypropylene/Clay Hybrid Materials. Macromolecules, 34:1864-1872. https://doi.org/10.1021/ma001122e

[40] Wagener R. - Reisinger T. J. G. (2003): A rheological method to compare the degree of exfoliation of nanocomposites. Polymer, 44:7513-7518. https://doi.org/10.1016/j.polymer.2003.01.001

[41] Lohse D. J. - Milner S. T. - Fetters L. J. - Xenidou M. - Hadjichristidis N. Mendelson R. A. - Garcia-Franco C. A. - Lyon M. K. (2002): Well-defined, model long chain branched polyethylene. 2. melt rheological behaviour. Macromolecules, 35:3066-3075. https://doi.org/10.1021/ma0117559

[42] Schulze D. - Trinkle S. - Mulhaupt R. - Friedrich C. (2003): Rheological evidence of modifications of polypropylene by $\beta$-irradiation. Rheologica Acta, 42:251-258. https://doi.org/10.1007/s00397-002-0282-7

[43. Trinkle S. - Friedrich C. (2001): Van Gurp-Palmen plot: a way to characterize polydispersity of linear polymers. Rheologica Acta, 40:322328. https://doi.org/10.1007/s003970000137

[44] Trinkle S. - Walter P. - Friedrich C. (2002): Van Gurp-Palmen plot II - classification of long chain branched polymers by their topology. Rheologica Acta, 41:103-113. https://doi.org/10.1007/s003970200010

[45] Van Gurp M. - Palmen J. (1998): Time-temperature superposition for polymeric blends. Rheology Bulletin, 67:5-8.

[46] Utracki L. A. (1999): Polymer blends handbook. Netherlands: Kluwer Academic Publishers

[47] Khan, S. A. - Prudhomme, R. K. (1987): Melt Rheology of Filled Thermoplastics. Reviews in Chemical Engineering, 1987, 4, 205. https://doi.org/10.1515/REVCE.1987.4.3-4.205

[48] Krishnamoorti, R. - Vaia, R. A. - Giannelis, E. P. (1996): Structure and Dynamics of Polymer-Layered Silicate Nanocomposites. Chemistry of Materials, 1996, 8, 1728. https://doi.org/10.1021/cm960127g

[49] Chevallier C. - Becquart F. - Taha M. (2013): Polystyrene/polycarbonate blends compatibilization: Morphology, rheological and mechanical properties. Materials Chemistry and Physics, 139: 616-622. https://doi.org/10.1016/j.matchemphys.2013.02.006

Ref.:

Kracalik, Milan: Assessment of reinforcement in polymer nanocomposites using cumulative rheological parameters Építőanyag - Journal of Silicate Based and Composite Materials, Vol. 69, No. 3 (2017), 116-120. p. https://doi.org/10.14382/epitoanyag-jsbcm.2017.21

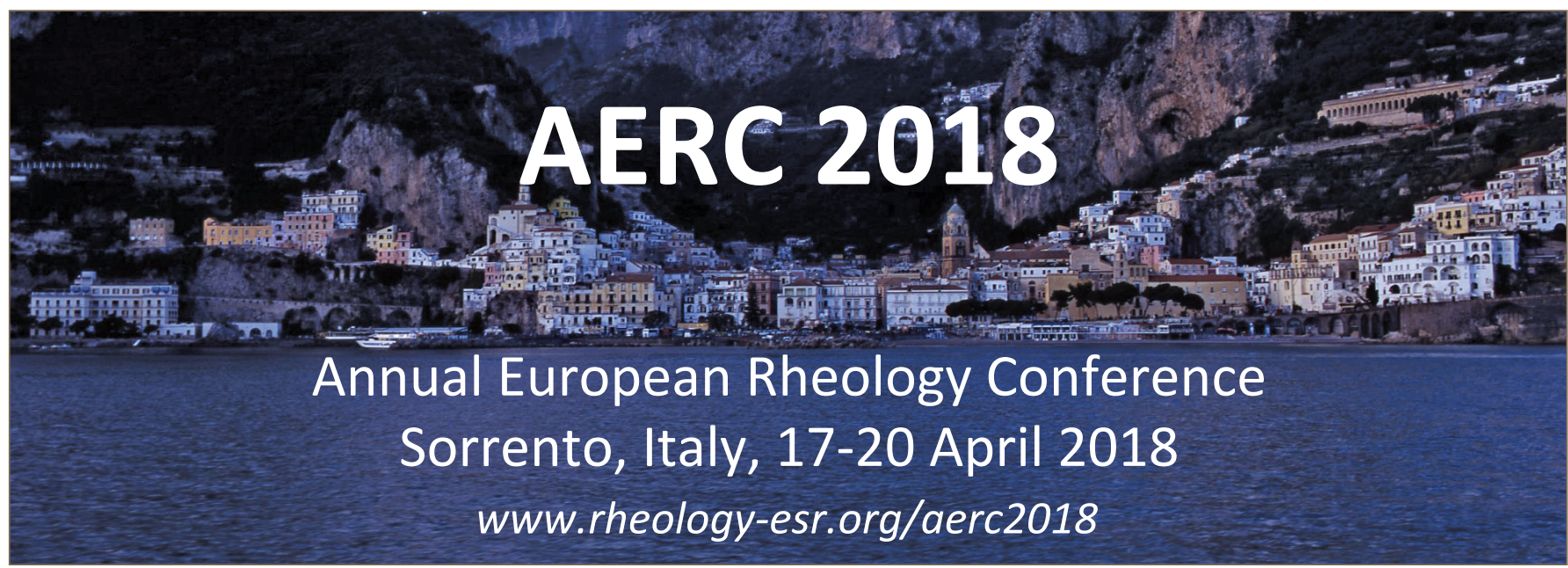

